Archived version from NCDOCKS Institutional Repository http://libres.uncg.edu/ir/asu/

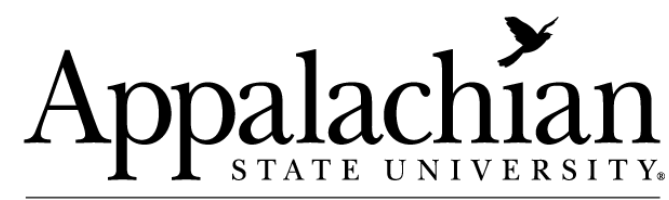

B O O N E, NORT H C A R O L I A

\section{Religious And Spiritual Journeys Of LGBT Older Adults In Rural Southern Appalachia}

\author{
By: Emily Dakin, Denise L. Levy, and Kelly A. Williams
}

\begin{abstract}
This article reports on religious and spiritual experiences of 11 lesbian, gay, bisexual, and/or trans*-identified (LGBT) older adults in rural southern Appalachia. Template analysis of interview data yielded themes including: harmful experiences with Christianity in childhood and adulthood, religion and spirituality as sources of support, current participation in supportive Christian churches, and personalized approaches to spirituality and religion. Despite prior harmful experiences in some cases, religion and spirituality now provided meaning, strength, and support for most of the participants. The article concludes with implications for theory, research, and professional practice for clergy, social workers and other helping professionals.
\end{abstract}

Emily Dakin, Denise L Levy \& Kelly A Williams (2021): Religious and spiritual journeys of LGBT older adults in rural Southern Appalachia, Journal of Religion, Spirituality \& Aging, DOI: 10.1080/15528030.2021.1985035. Publisher version of record available at: https://doi.org/10.1080/15528030.2021.1985035 


\title{
Religious and spiritual journeys of LGBT older adults in rural Southern Appalachia
}

\author{
Emily Dakina, Denise L Levy ${ }^{b}$, and Kelly A Williams ${ }^{a}$ \\ aDepartment of Social Work, Appalachian State University; 'Beaver College of Health Sciences, \\ Appalachian State University
}

\begin{abstract}
This article reports on religious and spiritual experiences of 11 lesbian, gay, bisexual, and/or trans*-identified (LGBT) older adults in rural southern Appalachia. Template analysis of interview data yielded themes including: harmful experiences with Christianity in childhood and adulthood, religion and spirituality as sources of support, current participation in supportive Christian churches, and personalized approaches to spirituality and religion. Despite prior harmful experiences in some cases, religion and spirituality now provided meaning, strength, and support for most of the participants. The article concludes with implications for theory, research, and professional practice for clergy, social workers and other helping professionals.
\end{abstract}

\section{KEYWORDS}

Religion; spirituality; Rural

Appalachia; older adults; LGBT

In the United States, the number of people who identify as religious and as Christian has declined in recent years, with more and more individuals identifying as spiritual (PEW Research Center, 2019). Still, approximately $75 \%$ of people in the United States identify as religious and $65 \%$ as Christian (PEW Research Center, 2019), and religion is often a significant or primary aspect of identity. Although some people of faith and religious communities have examined and changed their views on sexuality and gender in recent years, prejudice against lesbian, gay, bisexual, and trans* (LGBT) individuals remains. In fact, religious people, especially those who are Muslim, Catholic, or Protestant and have literalistic views, are more likely to have negative attitudes towards LGBT individuals than unaffiliated or spiritual individuals (Cragun \& Sumerau, 2015; Jackle \& Wenzelburger, 2015). Further, although a diversity of beliefs is present in individual congregations, many religious groups officially denounce LGBT identities in their policies and doctrines (Levy, 2014). This context may lead to difficulties for people who are LGBT and religious.

Even with potential conflicts between LGBT and religious identities, more than half of all LGBT individuals identify as religious (Conron et al., 2020). LGBT people of faith resolve identity conflicts in a variety of ways, including 
prioritizing one identity over another, integrating their identities, compartmentalizing their identities, modifying their religious beliefs, and/or finding welcoming communities (Dunn \& Creek, 2015; Levy \& Edmiston, 2014; Levy $\&$ Harr, 2018). Many LGBT individuals experience grief, loss, rejection, and trauma as part of this process, and inevitably are forced or choose to leave their faith communities (Cockayne et al., 2020; Hansen \& Lambert, 2011; Panchuk, 2018; Wood \& Conley, 2014). Some do report finding welcoming and affirming communities that both enhance their faith and honor their LGBT identities (Foster et al., 2015; Porter et al., 2013).

Although research tends to focus on the negative conflicts and discrimination faced by LGBT people of faith, a growing number of studies focus on the positive experiences and aspects of religion for LGBT individuals (Foster et al., 2015). For instance, LGBT religious and spiritual individuals have reported experiencing love and acceptance based on their LGBT identities, developing feelings of deep meaning and purpose, passionately living their spiritual values, having positive and authentic relationships, and developing spiritual strength (Rosenkrantz et al., 2016).

\section{Religion and spirituality in LGBT older adults}

The literature on religion and spirituality in LGBT individuals highlights some common outcomes for LGBT individuals of all ages. For instance, LGBT individuals of all ages have both positive and negative experiences with their faith communities, and report coping with negative experiences by developing personal belief systems, finding affirming congregations, and reducing participation in non-affirming faith communities (Dunn \& Creek, 2015; Foster et al., 2015; Levy \& Edmiston, 2014; Levy \& Harr, 2018; Porter et al., 2013). In a study with older adult LGBT individuals, Brennan-Ing et al. (2013) found similar outcomes.

Brennan-Ing et al.'s (2013) study is part of an emerging body of research focused specifically LGBT older adults (Swartz et al., 2015). This emerging literature highlights the unique experiences of LGBT older adults. To begin with, compared to younger LGBT individuals, LGBT older adults grew up in a time that was less accepting and more homophobic, when the internet and online supports were non-existent, and when there were fewer welcoming faith communities (Levy, 2014; Sullivan, 2003).

Another difference is that older LGBT individuals are more likely to be religious than younger LGBT individuals, with almost $65 \%$ of LGBT individuals over 65 identifying as religious (Conron et al., 2020). In fact, the Caring and Aging with Pride Project found that 38\% of LGBT older adults participate in religious or spiritual activities at least once per month, with the highest attendance among transgender older adults (48\%) and bisexual men (54\%), and the lowest attendance among gay men (35\%) (Fredriksen- 
Goldsen et al., 2011). Religiosity in LGBT older adults is not surprising, especially considering that Fowler's (1981) stages of faith shows that many people move into the last stages during this time. The conjunctive faith stage typically occurs in mid life when individuals understand their own truths as multidimensional, relative, and contradictory. Some individuals then transition into Fowler's final stage, universalizing faith, where they become passionately committed to transforming their worlds through social justice advocacy and selfless acts.

Although LGBT older adults are likely to be more religious than younger LGBT individuals, the literature highlights how religious affiliations can change from childhood to older adulthood, with older LGBT adults reporting decreased affiliation with Catholic and Christian denominations and increased affiliation with Buddhism, other religions or no religion (Escher et al., 2019). Gay and bisexual men may also have unique experiences that do not necessarily follow the same tragectory of being more relgious as they age. For example, a study with HIV positive gay and bisexual men found that the men were less likely to be spiritual or religious as they aged (Hampton et al., 2013). This suggests that there may be unique factors influencing the religious and spiritual beliefs of LGBT older adults that are worth investigating further.

Finally, compared to straight and cisgender older adults, LGBT older adults rely more on community and "chosen family" support as they age and less on family caregivers and formal services (Knauer, 2016). This may be due to rejection from family members, service providers, and faith communities. In fact, because of their intersectional identities, LGBT older adults may face compounding discrimination based on homophobia, heterosexiam, transphobia, ageism, isolation, and, for people of color, racism (Woody, 2014). As we seek to understand the religious and spiritual experiences of older LGBT adults, it is important to keep intersectional identities in mind, particularly given the historical homophobia and transphobia present in some religious communities.

\section{LGBT people of faith in Rural Appalachia}

\section{Rural settings}

This study focuses in particular on the experiences of LGBT older adults in rural southern Appalachia. When compared to those living in urban or suburban environments, LGBT individuals in rural locations often have less access to information, resources, and welcoming faith communities. They may be less likely to be out about their sexual and gender identities than their counterparts in urban areas (Butler, 2017) and/or delay coming out until they are fully independent. This is often due to fears or experiences of abandonment and the messages coming from their religious family, friends, and 
community members that link "homosexuality" with labels such as "sinful," "abomination," and "punishment or worthy of hell" (Cawood, 2018, pp. 41-47).

LGBT adults also report positive aspects to living in rural contexts. For instance, in Woodell et al.'s (2015) study with 24 Christian LGB individuals living in rural areas, participants embraced their rural locations as spaces for privacy, freedom and community. They also perceived urban LGB culture as a place for substance use and partying, and were not interested in those activities. Although many sought welcoming and affirming faith communities, some had to drive up to two hours to more urban areas to attend those churches. Still, most reported maintaining personal faith and finding local churches where they felt comfortable, even if those churches were not specifically affirming. In another study, Hansen and Lambert (2011) explored experiences of four lesbians living in rural communities and found that, while growing up, participants lacked exposure to other lesbian or gay individuals or information about being lesbian. However, three of the four were able to identify welcoming or accepting churches in their rural communities.

\section{Rural Appalachia}

Appalachia, which spans from northern Mississippi to southern New York and includes 205,000 square miles, provides a specific and unique rural context (Appalachian Regional Commission, n.d.). Although Appalachia is often identified for its high poverty rates, poor health factors, lack of trust of outsiders, and isolation and seclusion; it also has a distinct culture that includes spirituality and religion (Linscott et al., 2016; Savla et al., 2019). In Linscott et al.'s (2016) qualitative study with older adults in Appalachia, participants noted a distinction between religion and spirituality and explained that living in Appalachia had an influence on both their religion and spirituality. Religion has to do with an organized activity or practice (Linscott et al., 2016). For instance, living in close-knit communities for generations meant that small church communities were integrated into everyday life. This is especially true where the Appalachian region overlaps with the Bible Belt region of the country (in the Southeastern United States). In this part of the country, Evangelical Protestant groups, such as Southern Baptist and nondenominational churches, are prominent. Spirituality is often associated with a belief system and how someone lives their life, and this was ubiquitous in Appalachian communities (Linscott et al., 2016).

Another study that examined the social support experiences of transgender adults between the ages of 19 and 64 living in central Appalachia found that $24 \%$ of the participants (4 transwomen, 2 transmen) received support from their pastors and some congregation members, and generally viewed a number of faith congregations in the region as supportive (Aaron, 2015). Further, one transwoman participant described her personal relationship with God as 
a significant source of support throughout her transition, with God providing supportive and encouraging messages such as, "everything's not going to be perfect . . . . but ... it will get better" (Aaron, 2015, p. 86).

Even if LGBT individuals living in these close-knit rural communities in Appalachia do find some support, they also face hardships. Appalachian communities that are religious may not be accepting of LGBT individuals. In Eldridge et al.'s (2006) study of college students' attitudes towards same-sex sexuality in central Appalachia, they found that approximately one-third of the 123 respondents reported feeling uncomfortable around gay and lesbian individuals while one-fourth reported feeling comfortable. Another study that examined the experiences of four queer young adults living in rural Appalachia, found the most common code to emerge from the interviews to be the "religious environment" (Jordan, 2015, p. 23). All of these young adults described ways in which the religious environment in which they lived had harmed or limited their identity development and self-acceptance in some way.

To summarize the literature, LGBT individuals in general report both positive and negative experiences related to faith and spirituality. There are many ways in which they cope with negative or discriminatory experiences, including withdrawing from non-affirming faith communities, adapting their own personal beliefs, and finding welcoming faith communities. LGBT older adults have unique experiences based on the time periods in which they grew up and their increased religiosity. The context of rural southern Appalachia may be especially difficult for LGBT older adults who often need community support as they age, and research to-date paints a mixed picture in terms of religious support of LGBT individuals in the Appalachian context. Although LGBT older adults living in rural southern Appalachia may face unique challenges, not much is known about this population. No study to date has focused specifically on the religious and spiritual issues faced by these individuals. This paper seeks to fill this gap in the literature, and focuses on the southern region of Appalachia that intersects with the Bible Belt. It reports specifically on the religious and spiritual themes gleaned from a larger qualitative study of LGBT older adults in the region.

\section{Methodology}

\section{Purpose of study}

The data in this paper is from a larger needs assessment of LGBT older adults in rural southern Appalachia. Elsewhere [citation redacted], we report on findings related to social support and social networks, and experiences and needs regarding formal services. The section of our interview guide that focused on social support included a question about participants' involvement 
in religious or spiritual activities. Our interviews yielded rich data about the role of religion and spirituality in our participants' lives that included and extended beyond this one question about religion and spirituality as a source of support. Although religion and spirituality were not a primary focus of the original needs assessment, the rich and unexpected data about religion and spirituality led us to further explore and present here on these themes from the parent study.

\section{Participants}

Eligibility criteria for the needs assessment included being 60 or above; identifying as lesbian, gay, bisexual, and/or transgender; and living in the southern Appalachian region on a full-time basis. We interviewed 11 participants ages $60-88$ in this study. This included three married or partnered couples (six participants), three single participants, one partnered participant (whose partner did not participate in the study), and one widowed participant. Ten of the 11 participants were cisgender, and one was transgender. All of the participants identified as being either gay (three) or lesbian (eight). All of the participants were white, and 10 of the 11 participants possessed a bachelor's degree or higher; of these, six possessed a graduate degree.

We recruited participants for our study through several approaches. Information about our study was shared through welcoming and affirming faith communities in the area, the local senior center, and through a lesbian listserv. In addition, we used snowball sampling, and asked participants to contact others who were eligible to participate. We also partnered with several area residential long-term care facilities to recruit participants, although we were unable to identify any participants this way. In all cases, so as to avoid coercion, interested participants initiated contact with the project team.

\section{Data collection}

We received IRB approval before beginning our interviews. Also, a project leader provided training in qualitative interviewing to all team members before beginning interviews. Participants were interviewed in a private location of their choice. This was most commonly the participant's home, but also included private meeting rooms within the university and county libraries. Interviews ranged from about 30 minutes to two hours in length. Married or partnered participants (three couples participated in the study) were interviewed separately. The interviews were recorded and transcribed. 


\section{Data Analysis}

We performed a template analysis on the transcribed interviews, aided by the qualitative data analysis software NVIVO Pro 12. Template analysis is a lesser known and fairly recent form of thematic analysis emerging out of phenomenology and grounded theory traditions (Brooks et al., 2015). Its hierarchical approach to coding is beneficial in offering a balance of structure and flexibility (Brooks et al., 2015). Qualitative researchers using template analysis create and apply an initial coding template to the data, and then further refine and re-apply successive coding iterations until arriving at a final coding structure that encompasses all of the relevant data (Brooks et al., 2015). We were drawn to using template analysis because it allows researchers to begin with a predetermined coding structure when creating the initial coding template (Brooks et al., 2015). This appealed to us since we wanted to frame our coding structure around our interview guide, with subcodes developed based on themes from the participant responses. Our coding template was developed through an initial coding template, and then further refined through 10 successive iterations, with the 10th iteration being identified as final, in that it encompassed all relevant data. We fully coded all 11 transcripts in each coding iteration.

We included two measures to enhance trustworthiness within our data analysis (Lincoln \& Guba, 1985). First, each iteration of the coding template was coded independently by two coders, who then met to review and discuss their respective codes until they reached consensus. In addition, we performed member checks by providing a summary at set intervals during each interview. At these summary points, each participant could provide confirmation or clarification about the interviewer's understanding of what the participant was trying to say.

\section{Results}

This section reports on codes developed through the parent study, as well as additional comments about religion and spirituality that did not fit cleanly within the final coding template of the parent study (since religion and spirituality were not a primary focus of the parent study).

\section{Early life experiences}

The participants had all moved to southern Appalachia from elsewhere, and had lived in the region from 11 to 48 years at the time of their interview. Although participants were not specifically asked where they had grown up, five participants indicated that they had grown up in a southern state (Alabama, Florida, Georgia, or North Carolina), while three participants indicated that they had grown up in a Northern state (New Jersey or 
Pennsylvania). Additional places where participants had lived, either as an adult or at unspecified points in time, included Arkansas, Iowa, Ohio, Maryland, Minnesota, New York, and Ohio.

Interviews yielded information about the religious upbringing of six participants. One participant was raised Catholic, one was raised Jewish, and one was raised Dutch Reform. None of these participants indicated whether or not they had received any kinds of religious messages while growing up related to sexual orientation or gender identity. In addition, three participants described growing up in the Southern Baptist Church with religious theology that was in opposition to their sexual orientation. Participant 3, a cisgender woman who came out as a lesbian in high school, stated that her sexual orientation was not accepted by the church or her parents. Participant 4, a cisgender woman who identified as a lesbian, was raised in the Southern Baptist tradition within a large extended family, and grew up attending a church that was founded by her relatives. Therefore, with her, family and the church were essentially one and the same. This was idyllic in some respects, as she described being surrounded by loving and nurturing family members, and yet also extraordinarily painful as her relatives learned of her sexual orientation:

\begin{abstract}
Participant 4: my grandmother, mother's mother, wasnotsupportive atall.And thattook a while to change. Imean it tookyears... I never really talked to her abouthow she finally came to grips with whatever she came to grips with. Butshe continued to seem to love me. Butshe-forexample, when shefound outaftermyparentsfound out, shesentme countless letters here that were not good. They had all this religion stuff in them, and every one Iopened wasjustheartwrenching and breaking. But of course thatwashard, butthrough it all of it I knew that I had to be what I had to be. And that was the goal. That was what I was going to have to do in order to be happy. And I didn't really like making anyone else unhappy, but I saw no other way to do what I needed to do.
\end{abstract}

Participant 9, a cisgender man, was raised in a strict fundamentalist Southern Baptist church community where dancing and swimming with members of the opposite sex were not allowed. Participant 9 had self-identified as gay since he was a teenager. Throughout his life, he had maintained a very close relationship with his parents, who were still alive at the time of his interview. His sexual orientation was not discussed within his family, which seemed to be a way of maintaining closeness by avoiding the potential conflict posed by a religious belief that was opposed to same-sex sexuality. When asked about what supports he receives from his family of origin, he responded:

Participant 9: Emotional support. Not because I'm gay, but because I'm their son and we have a very close family. In terms of my being gay, we just really don't talk about it.... Because they're still very fundamentalist in their religious beliefs.... And [me being gay] makes them uncomfortable. My father's 91 and mymom's 82, and so Ijust don't lie a lot of that on them. 


\section{Religion and harm and adulthood}

In addition to the childhood experiences described above, two participants talked about more recent harmful experiences with religion relating to their sexual orientation or gender identity. Participant 3 described having attended a church as an adult where the pastor was fired based on their LGBT identity, and this prompted Participant 3 to leave this church. At the time of the interview, Participant 3 was a member of a welcoming and affirming faith community in the region. Additionally, our study's one transgender participant described an incident three or four years previously in which several congregants at a church she attended "outed" her to the church leadership, as described in the following quote:

Participant 1: [The congregants] went to the head of the church, went to the whatever, head of the church, people in charge there, and talked to them about me. Exposed me to the head of the congregation. If they had left it alone, I could-we've been told not to draw attention to ourselves. They drew attention to me. You know what they told the pastor and her husband? ... That I couldn't come, go to church like this. That I had to come as my birth gender. That's discrimination. . . . And you know what? It also goes against God. It's also denied me the right, that's God's house, it is not their house. I'll grant it it's their church but when it gets down to it, that is God's house. And in the Bible it says that, it says, that, something about everyone has a right or something to come, is welcomed in my house or something. . . . And see, they are denying me to go into my Lord's house. Everybody is welcomed. He even says it in the Bible.

Fortunately, this participant had found more welcoming faith communities since this incident. Taken all together, it is noteworthy that three of the four participants who had described previous harmful experiences with Christianity in either childhood and/or adulthood were involved in supportive, affirming Christian communities at the time of their interview. In other words, these experiences had not led to them either rejecting their LGBT identity or their Christian identity, but rather, these experiences led them to find Christian communities where their identities could be supported and reconciled. The additional participant, Participant 9, had adopted a kind of atheistic spirituality, as described in the personalized religion and spirituality section below, including a critical view of organized religion:

Participant 9: My personal belief is that organized religion keeps people from killing each other, from screwing around on their relationships, and some very basic set of morals. But, once spirituality develops past a certain level, religious dogma holds that back. And, that really it gets you to a certain level, but then you're done with it, you should get, put it away, and it answers spirituality beyond that of what an organized religion would provide for you. 


\title{
Religion and spirituality as source of support
}

Participants were asked the following question, "Religion and spirituality can be an important source of support for some people. Have you participated in any religious or spiritual activities in this area?" Nine of the 11 participants reported participating in religious or spiritual practices at the time of interview. Of the remaining two participants, Participants 7 reported being an atheist, and Participant 9 reported being a spiritual atheist.

\section{Women's spiritual community}

Three cisgender, female participants were or had been involved with women's spiritual groups. Two participants, who were married to each other, had moved to the area from a different state in the north 11 years previously, and still participated in a spirituality circle of several other women over the phone:

Participant 10: We have been members of a spirituality circle with several of the women for more than 25 years and when we moved here, we just, you know, we just used the phone. We just use the speaker phone.

The third participant had been involved in a (different) women's spiritual community, and stated

\begin{abstract}
Participant 2: I belonged to a women's group called [group name redacted] and we did weekend retreats for about 10 years and now I was one of the founders of it and ... so all the women who went through our program I'm real close to. And . . so I kinda have a big circle of friends. I really do, I, you know, I might not see them for a year but ... email I'll keep up with them on Facebook or whatever.
\end{abstract}

\section{Participation in formal religious organizations}

Seven of the participants were involved in formal church communities at the time of the interview. One participant (Participant 1), a transgender woman, was involved in several churches. The remaining six participants described positive experiences within welcoming and affirming faith communities. For instance, Participant 3, a cisgender woman, valued attending a church that aligned with her identity and religious beliefs

\footnotetext{
Participant 3: I do attend church and so I do have values that are, I believe, Christian values, don't have all that mainstream churches but I do have those values. I believe spiritual values and I think those are the same values of love one another and we are here to take care of each other. . . . And I do go to a church and I go to a church that is probably now 80 percent gay. So it's a very different environment than going to the [name of denomination].
}

Participant 6, a cisgender man who was married to Participant 5, described benefits of involvement in his church in terms of music and his sense of spirituality 
Participant 6: I'm spiritual not religious. [Spouse] is very strong Christian but his religion is [name of denomination], which there are no churches here. We like the music so we go to [name of church] for their concerts and that type of thing. ... We stay for the services. I don't take part in the Eucharist because I don't believe in that and nobody has pushed me about doing it. But it's a very, very nice church.

Participant 5, a cisgender man who was married to Participant 6 , described valuing support received from his priest

Participant 5: Well, I remember the first time that I went in to have hip surgery they asked me on the forms what relationship you had to a church and I put down [name of church] and the priest came in that morning before my surgery totally unexpected. I was very pleased that [priest].

Four participants described a sense of community they valued at their respective churches. For example, Participant 8 , a cisgender female, stated

Participant 8: Religion is not the thing that draws me to [name of church], it's the community and opportunities of becoming close to a large group of people that I like.

\section{Personalized spirituality and religion}

Seven participants described personal activities, beliefs, or identities that reflected a more individualized sense of spirituality or religion. Spirituality is a general belief system and how people live their lives, and religion is involvement in organized practices or activities (Linscott et al., 2016). Three described participating in women's spiritual communities, as described above, and two described themselves as being spiritual. For example, Participant 6, identifies as "spiritual not religious," while still attending a Christian church with his spouse. Participant 9, who is described above as having grown up in a fundamentalist Southern Baptist church community, explored other religions such as Hinduism and Buddhism, particularly when he was stationed in Nepal as part of the Peace Corps. At the time of interview, he reported some religious exploration and ultimately identified as being a spiritual atheist

\footnotetext{
Participant 9: I became really interested in both Hinduism and Buddhism. Both exist in [Nepal] and I really self-identified a lot with both of those religions . . . although I don't accept the [idea of] reincarnation-I'm an atheist and I came to terms with that quite a long time ago, but I do see a real need to develop one's spirituality ... there's nothing wrong with developing spirituality and ... you can have a belief system and accept and reject scientific ideas-the human brain is capable of doing both of those things
}

Two participants discussed Christian religious beliefs that they had developed over time to reconcile their religious beliefs with their sexual orientation or gender identity. Participant 1 reflected at length about her religious beliefs as they related to her sexual orientation and gender identity. As part of her journey, she examined what the Bible said about gender and sexuality, concluding that it 
did not say anything about being transgender. Ultimately, she has come to a place of acceptance of her identity, grounded in the belief that God loves her as she is, and perhaps even that being transgender was part of God's plan for her

Participant 1: I prayed at night, please God make me a girl, make me a girl or make me a boy, make me a boy, you know? ... I think God is, I don't know, I think maybe he loves his children and maybe this is part of what he wants, I suppose, to help other transgenders, you know. Maybe he knows something that I don't know, maybe he knows that it's something that me and others can't control.

Participant 3 had also come to a place of acceptance and peace about her understanding of God in relation to her lesbian identity:

Participant 3: Well, growing up Southern Baptist, I grew up with the, "you're going to hell", so that was an interesting message to hear as a gay child. But I knew at the end of the day that I was ok because I believe that there's grace in God. And I also believe that when it's time to meet my maker or whoever that there will be a conversation, that there will be "how have you lived your life"? And if you look at it from, I guess, a Christian perspective, of sin, not sin, that's why we have grace. If I kept doing it and I knew it was a sin then I think there would be a different conversation but I think God loves me for who I am and so I don't think that God will see it as a sin, might, but I believe we are here to just do the best that we can do.

In summary, many of the participants described personal spiritual and religious beliefs, identities, or activities, reflecting their own sense of religion or spirituality.

\section{Summary of the findings}

The participants in this study had lived in a variety of places in the south, northeast, and midwest of the United States and had lived in the southern Appalachian region from 11 to 48 years at the time of their interview. Most of the participants were involved with supportive religious or spiritual activities at the time of interview; three were involved with women's spiritual communities, and seven attended Christian churches. Participants described these communities as being meaningful in a variety of ways, including a sense of spirituality or connection to G-d, religious values, music, friendship, support, and community. Most of the participants also described a personalized sense of spirituality or religion, which could include developing their own spiritual or religious beliefs. These religious or spiritual beliefs included theological beliefs within the larger framework of Christianity, as well as a sense of spirituality outside of organized religion.

In some cases, participants spontaneously discussed childhood experiences with religion, for example, several of the participants described receiving religious messaging in opposition to their LGBT identity while growing up in the Southern Baptist church. This messaging could be quite painful, 
especially as their religious upbringing was heavily intertwined with their family upbringing, so these messages were also echoed within their families. Two of the participants had had harmful experiences in adulthood with religion as it related to their sexual orientation or gender identity. Importantly, participants' harmful earlier experiences with religion did not seem to act as a deterrent to being able to find supportive religious communities where their LGBT identity and Christian faith could be reconciled. Indeed most of the participants who described these earlier harmful experiences were active in supportive, affirming Christian communities at the time of their interview.

\section{Discussion and implications}

Our findings align with the existing literature on the religion and spirituality of LGBT individuals. Like our participants, LGBT individuals in other studies have described early faith and church experiences that were negative and traumatic, including discrimination and lack of acceptance (Brennan-Ing et al., 2013; Cockayne et al., 2020; Hansen \& Lambert, 2011; Levy \& Edmiston, 2014; Levy \& Harr, 2018; Murr, 2013; Wood \& Conley, 2014). Likewise, individuals often describe difficult family relationships (Dahl \& Galliher, 2012a; Foster et al., 2015; Levy \& Edmiston, 2014; Page et al., 2013). It is important to note that LGBT individuals in our study and in other studies (for example, Brennan-Ing et al., 2013; Foster et al., 2015; Porter et al., 2013; Rosenkrantz et al., 2016) also reported some positive aspects of or experiences with religion and spirituality. Often, these positive experiences are a result of finding affirming congregations and developing a personal belief system.

Research with LGBT individuals describes their experiences of resolving conflicts between sexual/gender identity and religion as a journey or process (Dahl \& Galliher, 2012b; Foster et al., 2015; Levy \& Edmiston, 2014; Levy \& Harr, 2018; Moleiro et al., 2013; Murr, 2013; Reinsmith-Jones, 2013). Many of our participants had resolved conflicts between their religious and LGBT identities through ways as described in previous research, such as integrating identities, modifying existing identities, modifying religious beliefs, and/or finding welcoming communities (Dunn \& Creek, 2015; Levy \& Edmiston, 2014; Levy \& Harr, 2018). In fact, most of our research participants were religiously involved, which is consistent with previous research finding that over half of all LGBT individuals identify as religious (Conron et al., 2020).

Personalized spirituality and religion was an important theme in our study and in previous research. As LGBT individuals move through their journeys, accept their sexual/gender identities, and make sense of negative messages they receive from faith communities, they develop personal theologies and personalized belief systems (Brennan-Ing et al., 2013; Foster et al., 2015; Hansen \& Lambert, 2011; 
Hattie \& Beagan, 2013; Levy \& Edmiston, 2014; Murr, 2013). In addition, they look for safe and welcoming faith communities (Brennan-Ing et al., 2013; Foster et al., 2015; Gandy et al., 2021; Lease et al., 2005). Bisexual and trans* individuals often have a more difficult time finding affirming communities and have unique experiences based on the assumptions and misconceptions individuals have about these populations (Gandy et al., 2021; Levy \& Edmiston, 2014; Levy \& Harr, 2018; Toft, 2014; Wandrey et al., 2015). This finding is consistent with the harmful religious described by our study's one transgender participant.

Our findings are also unique and build upon previous research in that they focus specifically on LGBT older adults in southern Appalachia. These individuals grew up in an era that was not as accepting and was more homophobic than today's society (Sullivan, 2003). As older adults, they have had time to develop their personal theology, faith, spirituality, and sexual/gender identity, and to address any conflicts they experienced between these identities. They are also at a time in their lives when individuals typically begin to rely on family members for care and support, and LGBT individuals are often relying on surrogate or chosen families (Knauer, 2016). Finally, the individuals in our study live in southern, rural Appalachia and in the Bible Belt, two areas of the country where religion, and often conservative religious ideology, permeates everyday life (Barton, 2010; Linscott et al., 2016; Savla et al., 2019).

\section{Limitations}

There are several limitations of this study, which also have implications for future research, as discussed below. First, the larger study that this paper is drawn from was not focused on religion and spirituality. We didn't ask specific

questions about religion and spirituality, with the exception of one question inquiring about participants' religion and spirituality as one of several domains of social support. Therefore, much of the data presented here was incidentally elicited from some of the subjects, so it is not possible to know how extensive or

prevalent the themes presented here actually were, or if additional themes might have emerged through specific questions. The data presented here reflect how, by its nature, qualitative research helps to elicit unanticipated information.

In addition, our sample was small, all white, and generally highly educated, and therefore not necessarily generalizable to the region. Although our sample is not diverse in terms of race, ethnicity, or level of education, this is consistent with

the area in which the research was conducted. In the counties where our participants reside, $94 \%$ of individuals are White and $89 \%$ have at least a high school diploma or equivalent (United States Census Bureau, 2019). Note also that small, non-representative samples are typical in qualitative research. Because of this, qualitative research is not intended to generate generalizable knowledge, but rather to provide enough descriptive information to enable future researchers to assess the transferability of findings across studies (Lincoln \& Guba, 1985). 


\section{Implications for professional practice}

Consistent with our findings, an LGBT older adult needs assessment study that gathered quantitative data using the LGBT Elders Needs Assessment Scale and qualitative data using focus groups, found that spirituality was one of seven identified areas of importance (Orel, 2014). It is important for social workers and other helping professionals to consider spiritual and religious factors as part of conducting a holistic assessment with LGBT older adults, to understand the implications of religious trauma, and to be aware of LGBT affirming faith organizations in their community (Cockayne et al., 2020; Levy et al., 2014; Levy et al., 2018; Panchuk, 2018). In addition, faith leaders should be competent in screening for mental health needs and resources for their members and partner with or refer to mental health professionals when appropriate (Bledsoe et al., 2013; Hall \& Gjesfjeld, 2013; Raedel et al., 2020; Stull et al., 2020).

Spiritual assessment instruments can greatly assist professionals in obtaining information about their clients' personal spiritual and/or religious histories if the client sees this as a relevant and salient area to include in their service plan (Puchalski \& Romer, 2000). Some of the existing spiritual assessment tools include the HOPE (Anandarajah \& Hight, 2001); the FICA (Puchalski \& Romer, 2000); the MIMBRA (Canda \& Furman, 2010), and the RCOPE (Pargament et al., 2000). Despite the unique spiritual and religious histories, experiences, and needs of LGBT older adults, there are currently no assessment tools designed specifically for this population. To address this gap in available tools for practitioners, we recommend the development of a spiritual assessment scale for LGBT older adults. Such a tool would consider harmful and traumatic experiences of rejection and discrimination by faith organizations, faith communities, and family members due to anti-LGBT religious-based beliefs. Conducting spiritual assessments that are sensitive to the unique experiences of LGBT older adults in the context of spirituality and religion would allow the helping professional to both provide support and connect the client to appropriate resources in the community (Cloyes et al., 2018).

\section{Implications for theory}

In addition to implications for practice, this study has implications for theories of faith development as well as for sexual and gender identity development. Based on Fowler's (1981) stages of faith, the LGBT individuals in this study, especially those who have personal theologies, are in the more advanced stages of faith. As Levy and Edmiston (2014) previously outlined, LGBT individuals may develop their faith quickly precisely because they are experiencing conflict between faith and gender/sexual identity. These kinds of conflicts encourage individuals to examine and question their religious upbringing much sooner 
than they might have otherwise. According to Fowler (1981), it may actually be easier to address these tensions earlier in life before ideologies and relationships become so established that they are hard to break away from. He explains that those who reach the individuative-reflective faith stage (four) have a "capacity for critical reflection on identity (self) and outlook (ideology)" (p. 182) that is similar to what we described in the section on personal theologies. Further, those who reach the final conjunctive faith stage (five) understand the multidimensionality and interrelatedness of all things as well as the limitations of their own consciousness and understanding (Fowler, 1981). Examples of faith development include Participants 9 and 3. Participant 9, for example, explored several different religions before becoming an atheist who also identifies as spiritual. Participant 3 highlighted the importance of her current spiritual values of loving and being of service to others, which she believes are Christian values, even if they are not practiced or promoted by all mainstream Christian churches.

Unlike faith development, gender and sexual identity development seems to slow down for LGBT individuals who experience identity conflicts and religious trauma, or those who do not have support from their families and/or community members (Cockayne et al., 2020; Levy \& Edmiston, 2014). In other words, when LGBT individuals do not have the support of their family, community, and religious leaders, it may slow down their own selfacceptance and their initial coming out to others. Our study seems to support this notion. For example, several participants in this study explained that they are not out to their family members or feel like they have to lead double lives. For example, Participant 11 said: "It's hard when you work with people and you can't talk about your personal life or if you do, you've got to watch your pronouns." Similarly, Participant 1 said she felt like she had to be "superman one minute and supergirl or superwoman the next." In other words, she has to be all things to all people, and is unable to be true to her authentic gender identity with all people and in all spaces in her life. Finally, Participant 3 described being in the "back of the closet for most of my life if not all of my life." These are some examples of barriers that LGBT individuals face during sexual and gender identity development, which can last a lifetime and may never result in the authentic synthesis of identity and pride that is a common final stage in theoretical models (Cass, 1984; Devor, 2004; Levitt \& Ippolito, 2014; Morgan \& Stevens, 2008; Paul \& Frieden, 2008; Roseborough, 2003).

\section{Implications for research}

There are a number of implications for research emerging from the findings discussed here. First, most of the themes discussed in this paper are incidental to the original research study, so we would recommend future research that specifically explored the themes discussed here. Future research should 
specifically ask participants about their early experiences with religion and family; experiences of religion and harm; religious and spiritual belief systems; and religion and spirituality as a source of support. In particular, we recommend future research focus on the unique population of older LGBT adults in rural southern Appalachia.

Prior research noted in the theoretical implications section above has found religious and spiritual development to be accelerated in an LGBT populations, whereas gender and sexual identity development seems to be slowed down for LGBT individuals who have experienced identity conflicts and religious trauma. Our data seems to support these findings, but, future research should more formally test these findings among older LGBT populations. Finally, as noted above, while spiritual assessment instruments can be helpful tools in clinical practice, there are currently no assessment tools specifically for LGBT older adults. This is significant because, as our findings show, LGBT older adults often have unique spiritual and religious histories and needs that might not be identified by existing assessment tools. The development of a spiritual assessment scale for LGBT older adults would be a valuable area for future research.

\section{Conclusion}

In conclusion, this study with older LGBT adults in rural southern Appalachia revealed unique themes related to religion and spirituality. Several of the participants reported hearing anti-LGBT messages from their families and/ or faith communities in early childhood, particularly those who were raised in the Southern Baptist tradition. For some, these harmful experiences with religion extended into adulthood. Despite these messages and experiences, most of the participants were involved with supportive religious or spiritual communities, and most had developed a personalized spirituality or religion. Future research should continue to explore the religious and spiritual experiences of this unique population. We hope this and future research will highlight the unique stories, resilience, needs, wisdom, and strength of older LGBT adults living in rural southern Appalachia.

\section{Disclosure statement}

No potential conflict of interest was reported by the author(s).

\section{References}

Aaron, A. J. (2015). Transgender individuals' social support experiences in central Appalachia [Doctoral Dissertation, University of Kentucky]. Theses and Dissertations - Educational, School, and Counseling Psychology. 48. https://uknowledge.uky.edu/edp_etds/48 
Anandarajah, G., \& Hight, E. (2001). Spirituality and medical practice: Using the HOPE questions as a practical tool for spiritual assessment. American Family Physician, 63(1), 81-99. https://doi.org/10.1016/S1443-8461(01)80044-7

Appalachian Regional Commission. (n.d.) About the Appalachian region. https://www.arc.gov/ about-the-appalachian-region/

Barton, B. (2010). "Abomination" - Life as a bible belt gay. Journal of Homosexuality, 57(4), 465-484. http://doi.org/10.1080/00918361003608558

Bledsoe, T. S., Setterlund, K., Adams, C. J., Fok-Trela, A., \& Connolly, M. (2013). Addressing pastoral knowledge and attitudes about clergy/mental health practitioner collaboration. Social Work \& Christianity, 40(1), 23-45.

Brennan-Ing, M., Seidel, L., Larson, B., \& Karpiak, S. E. (2013). "I'm created in God's image, and God don't create junk": Religious participation and support among older GLBT adults. Journal of Religion, Spirituality \& Aging, 25(2), 70-92. https://doi.org/10.1080/15528030. 2013.746629

Brooks, J., McCluskey, S., Turley, E., \& King, N. (2015). The utility of template analysis in qualitative psychology research. Qualitative Research in Psychology, 12(2), 202-222. https:// doi.org/10.1080/14780887.2014.955224

Butler, S. S. (2017). LGBT aging in the rural context. Annual Review of Gerontology and Geriatrics, 37(1), 127-142. https://doi.org/10.1891/0198-8794.37.127

Canda, E. R., \& Furman, L. D. (2010). Spiritual diversity in social work practice: The heart of helping (2nd ed.). Oxford University Press.

Cass, V. C. (1984). Homosexual identity formation: Testing a theoretical model. The Journal of Sex Research, 20(2), 143-167. https://doi.org/10.1080/00224498409551214

Cawood, J. C. (2018). Out in Appalachia: Leaving the closet in the mountains [Masters Thesis, Morehead State University]. ProQuest Number: 10826482.

Cloyes, C. G., Hull, W., \& Davis, A. (2018). Palliative and end-of-life care for lesbian, gay, bisexual, and transgender (LGBT) cancer patients and their caregivers. Seminars in Oncology Nursing, 34(1), 60-71. https://doi.org/10.1016/j.soncn.2017.12.003

Cockayne, J., Efird, D., \& Warman, J. (2020). Shattered faith: The social epistemology of deconversion by spiritually violent religious trauma. In M. Panchuk \& M. Rea (Eds.), Voices from the Edge: Centering marginalized perspectives in analytic theology (pp. 119140). Oxford University Press. https://doi.org/10.1093/oso/9780198848844.003.0006

Conron, K. J., Goldberg, S. K., \& O’Neill, K. (2020). Research that matters: Religiosity among LGBT adults in the US. UCLA School of Law Williams Institute. https://williamsinstitute. law.ucla.edu/publications/lgbt-religiosity-us/

Cragun, R. T., \& Sumerau, J. E. (2015). The last bastion of sexual and gender prejudice? Sexualities, race, gender, religiosity, and spirituality in the examination of prejudice toward sexual and gender minorities. The Journal of Sex Research, 52(7), 821-834. http://doi.org/10. 1080/00224499.2014.925534

Dahl, A., \& Galliher, R. V. (2012a). LGBTQ adolescents and young adults raised within a Christian religious context: Positive and negative outcomes. Journal of Adolescence, 35 (6), 1611-1618. https://doi.org/10.1016/j.adolescence.2012.07.003

Dahl, A., \& Galliher, R. V. (2012b). The interplay of sexual and religious identity development in LGBTQ adolescents and young adults: A qualitative inquiry. Identity: An International Journey of Theory and Research, 12(3), 217-246. http://doi.org/10.1080/15283488.2012. 691255

Devor, A. H. (2004). Witnessing and mirroring: A fourteen stage model of transsexual identity formation. Journal of Gay and Lesbian Psychotherapy, 8(1-2), 41-67.

Dunn, J. L., \& Creek, S. J. (2015). Identity dilemmas: Toward a more situated understanding. Symbolic Interaction, 38(2), 261-284. https://doi.org/10.1002/symb.146 
Eldridge, V. L., Mack, L., \& Swank, E. (2006). Explaining comfort with homosexuality in rural America. Journal of Homosexuality, 51(2), 39-56. https://doi.org/10.1300/J082v51n02_03 Escher, C., Gomez, R., Paulraj, S., Ma, F., Spies-Upton, S., Cummings, C., Brown, L. M., Tormala, T. T., \& Goldblum, P. (2019). Relations of religion with depression and loneliness in older sexual and gender minority adults. Clinical Gerontologist, 42(2), 150-161. https:// doi.org/10.1080/07317115.2018.1514341

Foster, K. A., Bowland, S. E., \& Vosler, A. N. (2015). All the pain along with all the joy: Spiritual resilience in lesbian and gay Christians. American Journal of Community Psychology, 55(12), 191-201. http://doi.org/10.1007/s10464-015-9704-4

Fowler, J. W. (1981). Stages of faith: The psychology of human development and the quest for meaning. Harper \& Row.

Fredriksen-Goldsen, K. I., Kim, H.-J., Emlet, C. A., Muraco, A., Erosheva, E. A., Hoy-Ellis, C. P., Goldsen, J., \& Petry, H. (2011). The aging and health report: Disparities and resilience among lesbian, gay, bisexual, and transgender older adults. Institute for Multigenerational Health. https://lgbtagingcenter.org/resources/pdfs/LGBT\%20Aging\%20and\%20Health\% 20Report_final.pdf

Gandy, M., Natale, A., \& Levy, D. L. (2021). "We shared a heartbeat": Protective functions of faith communities in the lives of LGBTQ+ people. Special joint issue of. Spirituality in Clinical Practice and Psychology of Religion and Spirituality.

Hall, S. A., \& Gjesfjeld, C. D. (2013). Clergy: A partner in rural mental health? Journal of Rural Mental Health, 37(1), 50-57. https://doi.org/10.1037/rmh0000006

Hampton, M. C., Halkitis, P. N., Perez-Figueroa, R., \& Kapprat, S. A. (2013). Religiousness, spirituality, and existential well-being among HIV-positive gay, bisexual, and other MSM age 50 and over. Journal of Religion, Spirituality \& Aging, 25(2), 160-176. http://doi.org/10. 1080/15528030.2012.739992

Hansen, J. E., \& Lambert, S. M. (2011). Grief and loss of religion: The experiences of four rural lesbians. Journal of Lesbian Studies, 15(2), 187-196. http://doi.org/10.1080/10894160.2011. 521103

Hattie, B., \& Beagan, B. L. (2013). Reconfiguring spirituality and sexual/gender identity: "It's a feeling of connection to something bigger, it's part of a wholeness.". Journal of Religion \& Spirituality in Social Work: Social Thought, 32(3), 244-268. http://doi.org/10.1080/ 15426432.2013.801733

Jackle, S., \& Wenzelburger, G. (2015). Religion, religiosity, and the attitudes toward homosexuality - A multilevel analysis of 79 countries. Journal of Homosexuality, 6(2), 207-241. http://doi.org/10.1080/00918369.2014.969071

Jordan, A. M. (2015). Those who choose to stay: Narrating the rural appalachian queer experience [Masters Thesis, University of Tennessee, Knoxville]. Tennessee Research and Creative Exchange. https://trace.tennessee.edu/utk_gradthes/3375

Knauer, N. J. (2016). LGBT older adults, chosen family, and caregiving. Journal of Law and Religion, 31(2), 150-168. https://doi.org/10.1017/jlr.2016.23

Lease, S. H., Horne, S. G., \& Noffsinger-Frazier, N. (2005). Affirming faith experiences and psychological health for Caucasian lesbian, gay, and bisexual individuals. Journal of Counseling Psychology, 52(3), 378-388. http://doi.org/10.1037/0022-0167.52.3.378

Levitt, H. M., \& Ippolito, M. R. (2014). Being transgender: The experience of transgender identity development. Journal of Homosexuality, 61(12), 1727-1758. https://doi.org/10. 1080/00918369.2014.951262

Levy, D. L. (2014). Christian doctrine related to sexual orientation: Current climate and future implications. In A. B. Dessel \& R. M. Bolen (Eds.), Conservative Christian beliefs and sexual orientation in social work: Privilege, oppression, and the pursuitof human rights (pp. 11-42). Council on Social Work Education Press. 
Levy, D. L., \& Edmiston, A. (2014). Sexual identity, gender identity, and a Christian upbringing: Comparing two studies. Affilia: Journal of Women and Social Work, 29(1), 66-77. https://doi.org/10.1177/0886109913509542

Levy, D. L., \& Harr, J. (2018). “I never felt like there was a place for me:” Experiences of bisexual and pansexual individuals with a Christian upbringing. Journal of Bisexuality, 18(2), 186205. https://doi.org/10.1080/15299716.2018.1431169

Lincoln, J. F., \& Guba, E. G. (1985). Naturalistic inquiry. Sage Publications.

Linscott, J., Randolph, A. L., \& Mayle, T. (2016). The impact of spirituality on wellness for Appalachian older adults. Adultspan Journal, 15(2), 96-108. https://doi.org/10.1002/adsp. 12024

Moleiro, A., Pinto, N., \& Freire, J. (2013). Effects of age on spiritual well-being and homonegativity: Religious identity and practices among LGB persons in Portugal. Journal of Religion, Spirituality \& Aging, 25(2), 93-111. http://doi.org/10.1080/15528030.2012.741561 Morgan, S. W., \& Stevens, P. E. (2008). Transgender identity development as represented by a group of female-to-male transgendered adults. Issues in Mental Health Nursing, 29(6), 585-599. http://doi.org/10.1080/01612840802048782

Murr, R. (2013). "I became proud of being gay and proud of being Christian": The spiritual journeys of queer Christian women. Journal of Religion \& Spirituality in Social Work: Social Thought, 32(4), 349-372. https://doi.org/10.1080/15426432.2013.839241

Orel, N. A. (2014). Investigating the needs and concerns of lesbian, gay, bisexual, and transgender older adults: The use of qualitative and quantitative methodology. Journal of Homosexuality, 61(1), 53-78. https://doi.org/10.1080/00918369.2013.835236

Page, M. J. L., Lindahl, K. M., \& Malik, N. M. (2013). The role of religion and stress in sexual identity and mental health among lesbian, gay, and bisexual youth. Journal of Research on Adolescence, 23(4), 665-677. https://doi.org/10.1111/jora.12025

Panchuk, M. (2018). The shattered spiritual self: A philosophical exploration of religious trauma. Res Philosophica, 95(3), 505-530. https://doi.org/10.11612/resphil.1684

Pargament, K. I., Koenig, H. G., \& Perez, L. M. (2000). The many methods of religious coping: Development and initial validation of the RCOPE. Journal of Clinical Psychology, 56(4),

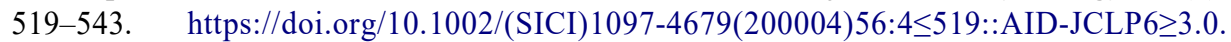
$\mathrm{CO} ; 2-1$

Paul, P. L., \& Frieden, G. (2008). The lived experience of gay identity development: A phenomenological study. Journal of LGBT Issues in Counseling, 2(1), 26-52. https://doi. org/10.1080/15538600802077509

PEW Research Center. (2019). In U.S., decline of Christianity continues at rapid pace: An update on America's changing religious landscape. https://www.pewforum.org/2019/10/17/in-u-s-de cline-of-christianity-continues-at-rapid-pace/

Porter, K. E., Corina, R. R., \& Witten, T. M. (2013). Religious affiliation and successful aging among older adults: Findings from the, Trans MetLife survey. Journal of Religion, Spirituality \& Aging, 25(2), 112-138. http://doi.org/10.1080/15528030.2012.739988

Puchalski, C., \& Romer, A. L. (2000). Taking a spiritual history allows clinicians to understand patients more fully. Journal of Palliative Medicine, 3(1), 129-137. https://doi.org/10.1089/ jpm.2000.3.129

Raedel, D. B., Wolff, J. R., Davis, E. B., \& Ji, P. (2020). Clergy attitudes about ways to support the mental health of sexual and gender minorities. Journal of Religion and Health, 59(6), 3227-3246. https://doi.org/10.1007/s10943-020-01033-4

Reinsmith-Jones, K. (2013). Transsexualism as a model of spiritual transformation: Implications. Journal of GLBT Family Studies, 9(1), 65-99. https://doi.org/10.1080/ 1550428X.2013.748509 
Roseborough, D. (2003). Conceptions of gay male life-span development: Past and present. Journal of Human Behavior in the Social Environment, 8(2/3), 29-53. http://doi.org/10.1300/ J137v08n02_03

Rosenkrantz, D. E., Rostosky, S. S., Riggle, E. D. B., \& Cook, J. R. (2016). The positive aspects of intersecting religious/spiritual and LGBTQ identities. Spirituality in Clinical Practice, 3(2), 127-138. http://doi.org/10.1037/scp0000095

Savla, J., Bivens, L. R., Roberto, K. A., \& Blieszner, R. (2019). Where you age matters: Individual- and county-level predictors of formal and informal care in rural Appalachia. Journal of Aging and Health, 31(5), 837-860. https://doi.org/10.1177/0898264318761907

Stull, L. G., Harness, J., Miller, M., \& Taylor, A. (2020). Attitudes about mental illness among seminary students: A qualitative analysis. Journal of Religion and Health, 59(5), 2595-2610. https://doi.org/10.1007/s10943-020-01045-0

Sullivan, M. K. (2003). Homophobia, history, and homosexuality: Trends for sexual minorities. Journal of Human Behavior in the Social Environment, 8(2/3), 1-13.https://doi.org/10.1300/ J137v08n02_01

Swartz, C., Bunting, M., Fruhauf, C. A., \& Orel, N. A. (2015). The meaning of spirituality in end-of-life decisions among LGBT older adults. In N. A. Orel \& C. A. Fruhauf (Eds.), The lives of LGBT older adults: Understanding challenges and resilience (pp.91-109). American Psychological Association. https://doi.org/10.1037/14436-005

Toft, A. (2014). Re-imagining bisexuality and Christianity: The negotiation of Christianity in the lives of bisexual women and men. Sexualities, 17(5/6), 546-564. http://doi.org/10.1177/ 1363460714526128

United States Census Bureau. (2019). https://data.census.gov

Wandrey, R. L., Mosack, K. E., \& Moore, E. M. (2015). Coming out to family and friends as bisexually identified young adult women: A discussion of homophobia, biphobia, and heteronormativity. Journal of Bisexuality, 15(2), 204-229. http://doi.org/10.1080/15299716. 2015.1018657

Wood, A. W., \& Conley, A. H. (2014). Loss of religious or spiritual identities among the LGBT population. Counseling and Values, 59(1), 95-111.http://doi.org/10.1002/j.2161-007X.2014. 00044.x

Woodell, B., Kazyak, E., \& Compton, D. (2015). Reconciling LBG and Christian identities in the rural South. Social Sciences, 4(3), 859-878. http://doi.org/10.3390/socsci4030859

Woody, I. (2014). Aging out: A qualitative exploration of ageism and heterosexism among aging African American lesbians and gay men. Journal of Homosexuality, 61(1), 145-165. http://doi.org/10.1080/00918369.2013.835603 